\title{
Contribution of the 3D Geological Model to the Study of the High Basin Ziz Jurassic Aquifers Structure (Central High Atlas, Morocco)
}

\author{
Nordine Nouayti ${ }^{*}$, Driss Khattach ${ }^{1}$, Mohamed Hilali ${ }^{2}$ \\ ${ }^{1}$ Laboratory of Applied Geosciences and Center of Eastern Science and Water Technology, Department of \\ Geology, Faculty of Sciences, Mohammed 1st University, Oujda, Morocco \\ ${ }^{2}$ Geology Department, Faculty of Science and Technology, University Moulay Ismail, Errachidia, Morocco \\ Email: " nordine.svt@gmail.com
}

Received 5 May 2015; accepted 25 June 2015; published 30 June 2015

Copyright @ 2015 by authors and Scientific Research Publishing Inc.

This work is licensed under the Creative Commons Attribution International License (CC BY). http://creativecommons.org/licenses/by/4.0/

cc) (i) Open Access

\begin{abstract}
The high Ziz's basin, which is part of the Central High Atlas, contains Jurassic superficial and deep aquifers. The information sheets are still fragmentary and insufficient because of the basin's large size and its complex geological structure. In order to improve the knowledge of these aquifers and the determination of the structure of aquifers, a 3D geological model was developed in this study. It was constructed from information provided by 200 mechanical soundings and 81 electrical surveys and geological maps. Compiled holes were analyzed, coded and integrated in the software Groundwater Modeling System 6.0 (GMS 6.0). For doing this, five lithostratigraphic units were considered: the Domerian, the Toarcian, the Aalenian, the Bajo-Bathonian and the Quaternary. The operation of the 3D stratigraphic model allowed making it closer to the geometry of Jurassic aquifers.
\end{abstract}

Keywords

Central High Atlas, Ziz's Basin, Jurassic Aquifers, 3D Stratigraphic Model

\section{Introduction}

The study area extends from the far east of the Central High Atlas to the western part of the High Atlas Oriental.

${ }^{*}$ Corresponding author.

How to cite this paper: Nouayti, N., Khattach, D. and Hilali, M. (2015) Contribution of the 3D Geological Model to the Study of the High Basin Ziz Jurassic Aquifers Structure (Central High Atlas, Morocco). Journal of Geographic Information System, 7, 294-300. http://dx.doi.org/10.4236/igis.2015.73023 
It is bounded to the north by the High Moulouya (Eastern Plateau), to the south by the Anti-Atlas Oriental. It contains surface and deep Jurassic aquifers. Groundwater from captive and superficial aquifers is water resources exploited by man for various uses [1].

The management of the aquifer requires a good knowledge of the aquifer, particularly its geometry.

The construction of a 3D geological model from field data and the basement can be a vital contribution to the understanding of the spatial organization of basement structures.

This paper presents a 3D geological model the height of Ziz basin by integrating all geological data from drillings, electrical surveys and geological maps.

\section{Geological Setting and Hydrogeological}

The study area extends from the extreme east of the Central High Atlas to the western part of the Oriental High Atlas. It is bordered to the north by the High Moulouya (Eastern Meseta), to the south by the oriental Anti-Atlas; generally have a secession of wrinkles and depocentre (Figure 1). It contains shallow and deep aquifers.

The geological map of the study area (Figure 1) was developed from the geological map Midelt 1/200,000 [2] and the geological map of Rich and Boudnib 1/200,000 [3]. Triassic, composed of detritus, basalt diabase and sometimes evaporites, depends in angular unconformity on the deformed Paleozoic basement and structured by several tectonic phases [4]-[6]. The Jurassic series form the major part of Mesozoic land of the High Atlas.It is based conformably on the red formations Triassic-Lower Lias. Their lithology consists essentially of dolomite, limestone, calcareous marl alternations and silico-clastic detritus [6]-[9].

Structurally, the expansion plan NW-SE, who reigned during the Triassic-Jurassic time, controlled the formation of the Atlas basins. Rifting is initiated from the Triassic, while the individualization of these basins and contemporary subsidence sedimentation took place during the Jurassic. The paleogeographic and morphostructural part is dominated at the time by a system of blocks tilted largely towards the NW and to the SE. These are limited by major NE-SW normal faults with ENE-WSW as separate from the WNW-ESE transfer faults

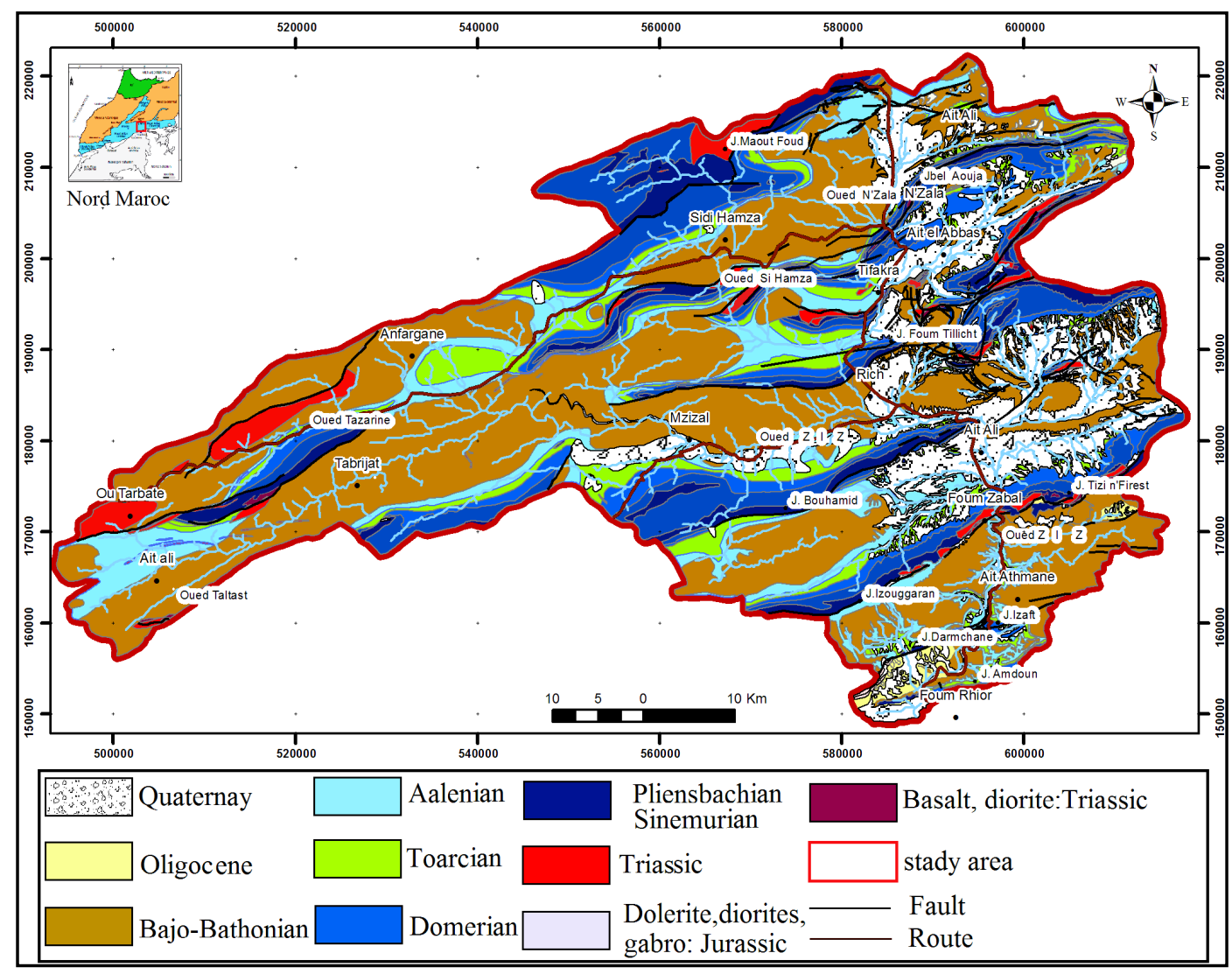

Figure 1. Geological map and location of the study area. 
[10]-[12]. Tertiary, a two episodic compression phase, first NW-SE and NS, took the old NE-SW normal faults as reverse faults or sinistral detachment-duplication. The transverse faults WNW-ESE trending dextral offsets are reactivated. This compression that initiates the closing of the Atlas basins from the Eocene materializes during the Oligo-Miocene and Pliocene-Quaternary [4]-[12].

Hydrologically, High Atlas contains a set hydrogeological units of communicating with each other: The Lias forming a relatively continuous system, Aalenian and Dogger. The Aalenian form and Dogger aquifer systems, fragmented into separate basins in each synclinal basin and usually without communication, sometimes with multiple aquifer levels. The waterproof series Toarcian-Aalenian separates between aquifers sets of lower Lias Domerian and those of the Aalenian Dogger. Communications between aquifers are only possible thanks holes [13].

The depth of the water, according to a survey conducted in February 2014 at twenty points of water varies from a few meters to more than sixty meters. Productivity can exceed $100 \mathrm{l} / \mathrm{s}$ in the Liassic formations fractured (FoumTillicht, Tazmamert, Kheng $\cdots$ ) with a mineralization generally less than $2 \mathrm{~g} / \mathrm{l}$. These aquifers give rise to several sources, the most important are those of Sidi Hamza Zaouiet.

\section{Data and Methods}

Like any model, the 3D structural model is at best a simplified view of reality that depends on the choice of the scale, prior assumptions about the characteristics of geological objects, quantity and quality of the information available and also limits on the software. Namely, the 3D geological model of the High Ziz basin was carried out on based of geological data from geologic maps [2], and recognition surveys in the study area. Indeed, the database used to build the model contains 81 electrical soundings [14] on behalf of the Directorate of Research and Planning Water were included in this study, 200 boreholes (Figure 2), executed from 1956 to 2014, including, the borehole $\mathrm{N}^{\circ} \mathrm{TMT} 1$ is the deepest.

It is run Timetroute to a total depth of $1831 \mathrm{~m}$ and intercepted the roof of the aquifer Domerian $1100 \mathrm{~m}$ and $400 \mathrm{~m}$ in Aalenian aquifer. The borehole did not reach the base of the Jurassic; we then took the maximum drilling depth considered for this limit. The acquired data were analyzed and selected, and then integrated into the software GMS 6.0 (Groundwater Modeling System 6.0). Thus, to construct the model we considered four lithostratigraphic units: Quaternary (code 1), Batho-Bajocian (code 2) Aalenian (code 3) Taoarcian (code 4) and Domerian (code 5). The modeling process includes the following steps: inventory of available boreholes; analysis

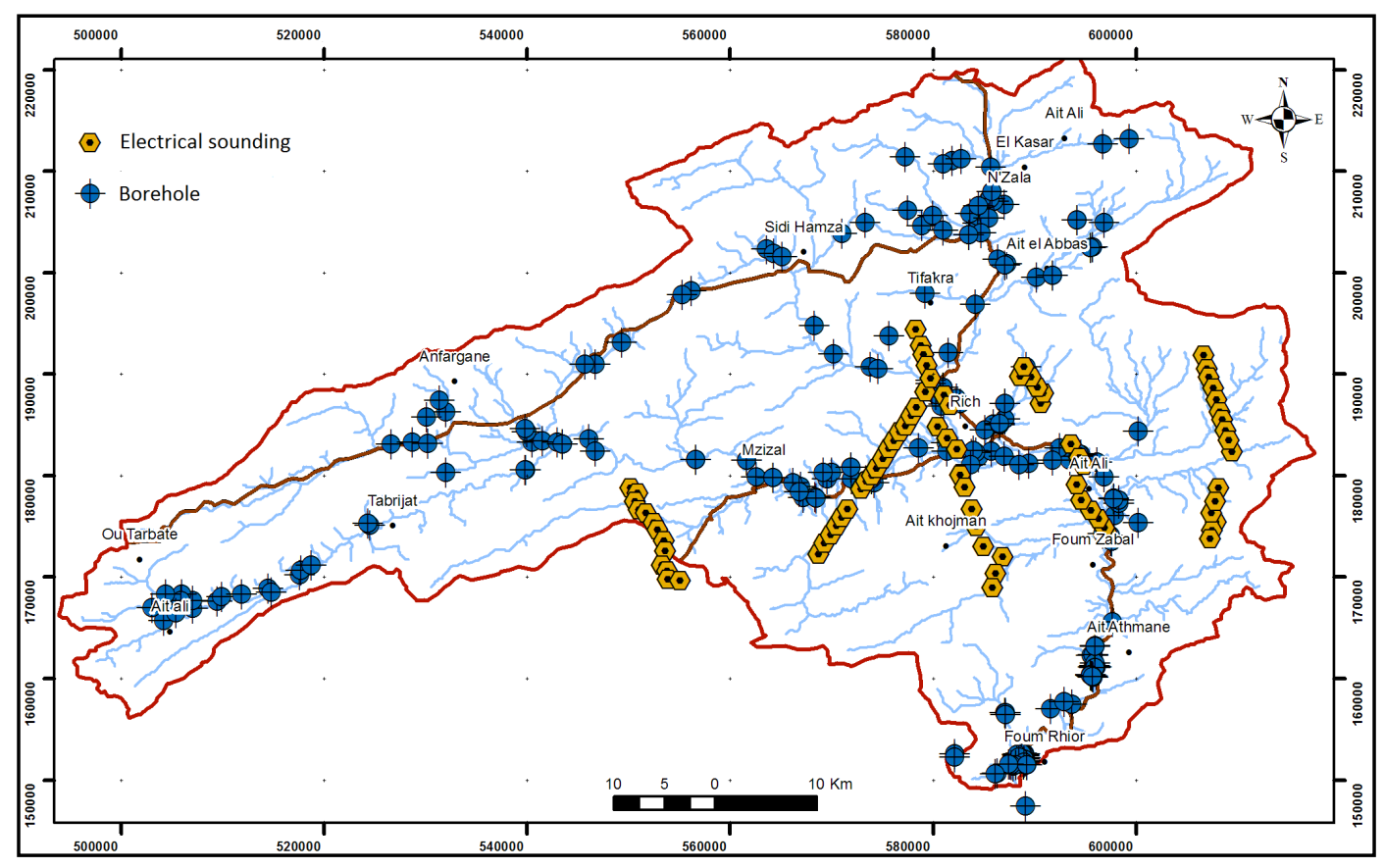

Figure 2. Distribution of the studied boreholes and vertical electrical soundings. 
of boreholes data; selection of boreholes to operate; realization of a database containing the details on the information $(\mathrm{x}, \mathrm{y}, \mathrm{z})$ of drilling, geological and $\mathrm{Z}$ coordinate encoding horizons; information integration in the GMS 6.0; model construction and exploitation of the model. GMS 6.0 allows for correlations between the different data and generate interpolated a conceptual model of geological horizons. It provides the possibility of realizing cuts in any location of the solid 3D model. It also allows you to view any stratum separately.

\section{Results}

\section{D Geological Model}

The elaborated three-dimensional model (Figure 3), based on the of available geological data and electrical surveys allowed us to visualize the architecture of the High Ziz basin, to realize out geological sections in all directions and at any location of the model and to monitor changes in depth Jurassic aquifers (Figures 3-8).

This 3D geological model has the advantage of being based on a number of exploratory boreholes. It allows to specify the geometry and structure of the High Ziz basin:

The model shows a series of anticlines and synclinal structures in the Jurassic basin with brittle structures of horst and graben and subsidence. The formations above the Domerian showing a very variable thickening affected by the deep tectonic (horst and graben structures) and subsidence very important, there is usually a bevel training in approaching outcrops Domerian. The Bajocian-Bathonian limestone-marl formation is predominantly

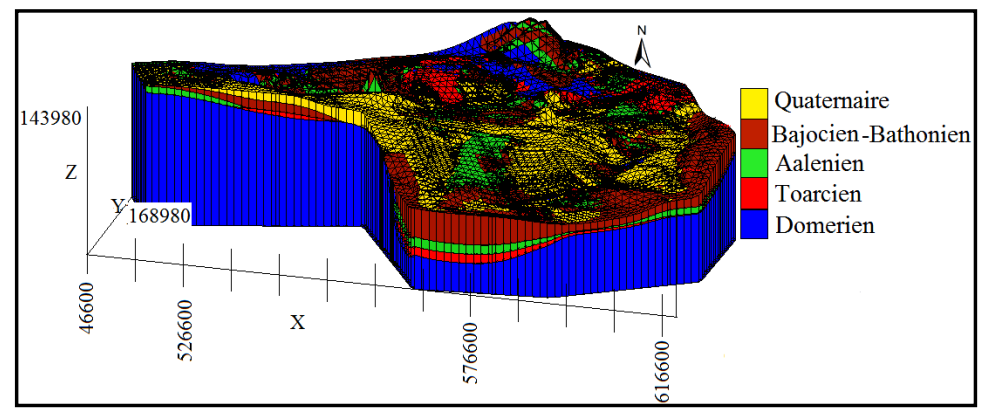

Figure 3. 3D geological model the height of Ziz basin.

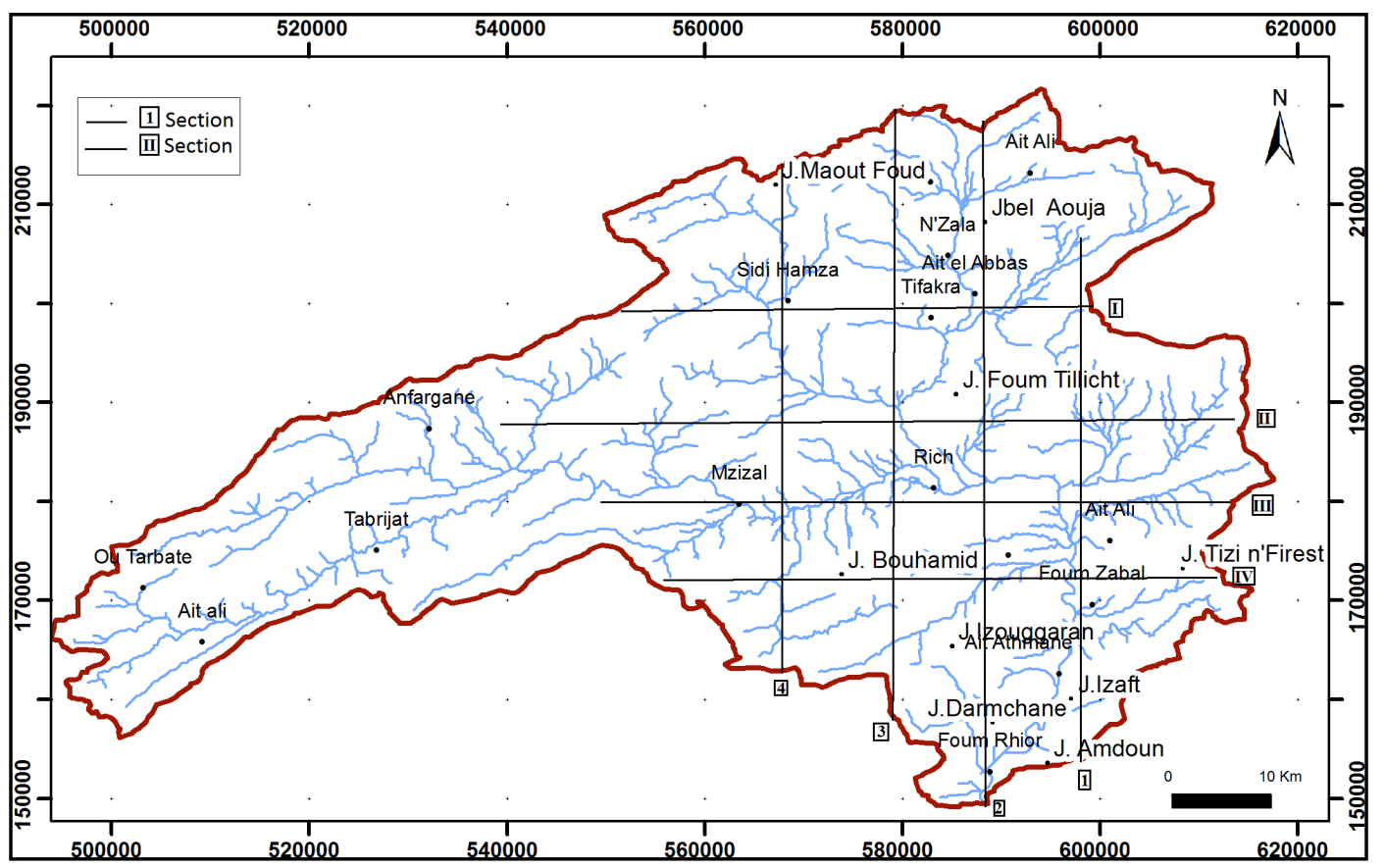

Figure 4. Location of geological sections. 


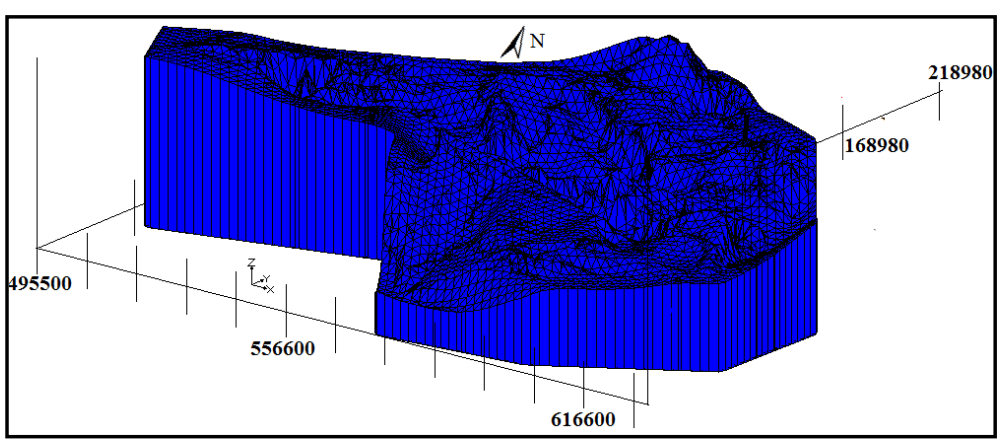

Figure 5. The Domerien structure.

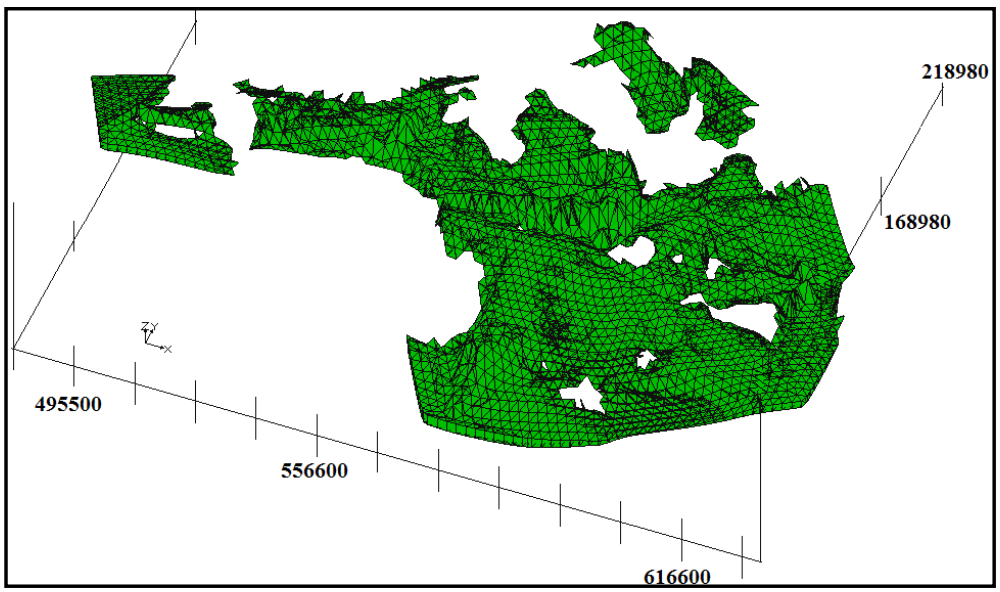

Figure 6. The Aalenien structure.

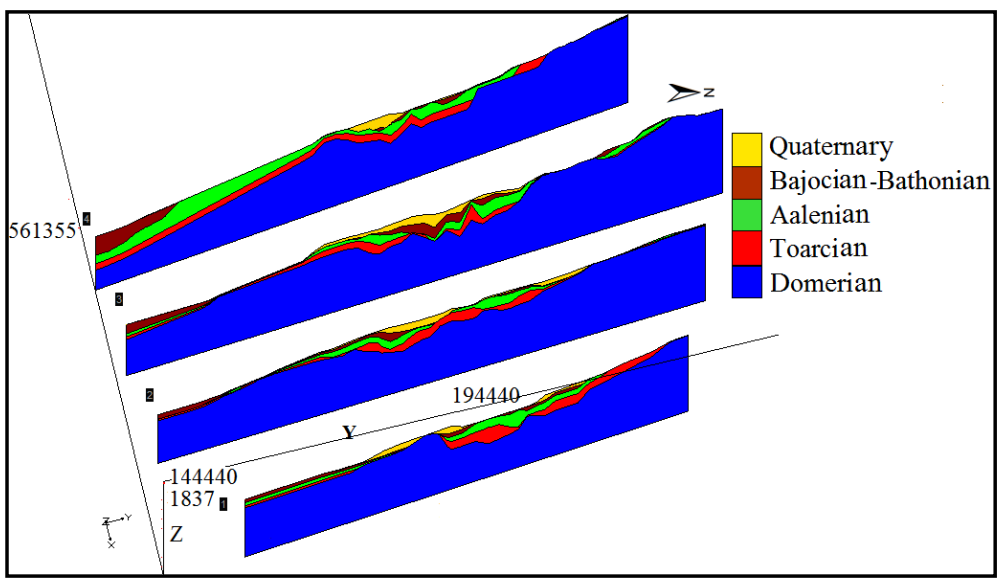

Figure 7. Sections North-South.

marl with variations of thickness 14 to $291 \mathrm{~m}$. It is waterproof level between the aquifers of the Quaternary and deep aquifers that start charging.

The Aalenian is predominantly limestone-marl limestone with thickness variations with depth roof varies from a few meters to $471 \mathrm{~m}$ (Figure 3, Figure 4, Figures 6-8). The Toarcian marly limestone is dominant and usually quite thick marl (up to $300 \mathrm{~m}$ thick on average). It is the bedrock (waterproof) of Aalenien and start charging the land underlying Domerian (Figure 3, Figure 7, Figure 8). The Domerian is limestone and marllimestone and is a very important aquifer, its depth is variable from one sector to another, it gradually decreases along outcrops and reaches its maximum at the center of $1015 \mathrm{~m}$ basin and in the south about 10 to $30 \mathrm{~m}$, then 


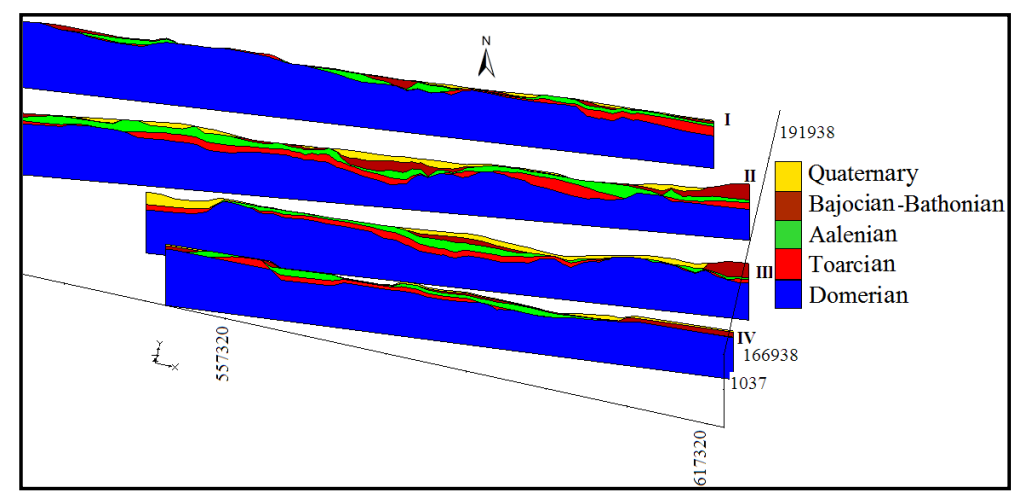

Figure 8. Sections West-East.

Domerian formations gradually sink to the south by the formations of Cretaceous basin (Figures 3-5, Figure 7, Figure 8). The model was used to identify potential areas of water evidence stokages or favorable areas for the implementation of useful prospecting boreholes according to area and according to the targeted aquifer.

\section{Discussion}

Any 3D geological modeling studies done so far in this area are only the work of structuralist advanced in these N-S sections [4] [7] [9] [11] [15], generally these studies have shown good agreement between the NS sections, but without details of Mesozoic strata especially those which close the aquifer, their thicknesses, shapes. Thus our study developed a 3D-Geological model allows to visualize the overall geometry of the basin and especially those of Jurassic aquifers, and benefit to make cuts in any location. This study has shown good agreement between results [16] [17] that records reductions of the thicknesses from north to the south and remarkable subsidence (Rich Errachidia).

Our results are in agreement with the results obtained by many authors [18], they were used to model the basins showed the modeling input to the recognition and geometry of tanks. The 3D model is the basis for future studies especially hydrodynamic modeling of aquifers and the numerical simulation and the vulnerability of the aquifer to pollution and its management.

\section{Conclusions}

The main results obtained in this study will improve the knowledge on the structure and the geometry of the top of Ziz basin. The 3D geological model of the basin is developed on the basis of data provided by 200 boreholes, 81 electrical surveys, and geological maps. Although the model does not include faults, it can, however, view the general architecture of the basin. Thus, the 3D geological model showed the structure of the Central High Atlas manifested by successive structures anticlines and synclines.

The area is affected by a very turbulent tectonic ductile and brittle. The model allowed us to approach the depth of the deep aquifer of high Ziz anywhere within the study area, and to follow its evolution in depth. Indeed, the Domerian which is a deep and continuous tank flush with crests (anticlines) and gradually sinks under the latest formation, depth of their roof varies from one sector to another and usually it's deep in heart synclines (10 to $1015 \mathrm{~m})$.

The Toarcian marl which is dominant, usually quite thick, is a generally continuous formation (300 m thick on average).

The formation of the Aalenian, Bajocian-Bathonian is discontinuous and generally occupies the synclinal structures and bevel by approaching Domerian formations at the anticlines, these courses may have reduced their thicknesses near the Domerian (anticlines). The limestone formations Aalenian are fragmented into separate pools in each synclinal basin and generally without communications, the depth of the roof varies between approximately $471 \mathrm{~m}$ meter.

The results of this study show the importance of the integration of geological and boreholes and electrical soundings data into a 3D model to explore the deep aquifer systems. 


\section{Acknowledgements}

The authors thank the Basin Agency Hydraulic Guir, Rhéris et Ziz for providing the data on the studied boreholes.

\section{References}

[1] Prasad, B. and Narayana, T. (2004) Subsurface Water Quality of Different Sampling Stations with Some Selected Parameters at Machilipatnam Town. Nature Environment and Pollution Technology, 3, 47-50.

[2] Gonzague, D. and Despujols, M. (1939) Carte géologique de Midelt au 1/200,000. Publiée par le service géologique du Maroc.

[3] Lyazidi, M., Eyssautier, L., Marcais, J. and Choubert, G. (1956) Carte géologique de Rich et Boudnib au 1/200,000. Publiée par le service géologique du Maro.

[4] Chafiki, D., El Hariri, A., Souhel, A., Lachka, N., Sarih, S., Dommergues, J., et al. (2007) Données lithostratigraphiques et biostratigraphiques sur le Lias dans le cadre de deux transects du Haut Atlas central (Beni Mellal et MideltErrachidia, Maroc). Journal of African Earth Sciences, 49, 90-102.

[5] Charrire, A. (1990) Héritage hercynien et évolution géodynamique alpine d'une chaine intracontinental: Le Moyen Atlas au S de Fès (Maroc). Thèse Doct. Etat, Toulouse, 589.

[6] Hinaje, S. (1995) Apport de l'analyse de la tectonique cassante tardi et post-panafricane à la modélisation de la mise en place des miniralisations dans la boutoniére de Bou-Azzer (Anti-Atlas, Maroc). Thèse de 3ème cycle, Faculté des Sciences Rabat, 238.

[7] Piqué, A., Charroud, M., Laville, E. and Amrha, M. (2000) The Tethys Southern Margin in Morocco: Mesozoic and Cainozoic Evolution of the Atlas Domain. Mémoires du Museum National d'histoire Naturelle, 182, 93-106.

[8] Igmoullan, B., Sadki, D., Fedan, B. and Chellai, E.H. (2001) Evolution géodynamique du Haut-Atlas de Midelt (Maroc). Pendant le Jurassique: Un exemple d'interaction entre la tectonique et l'eustatisme. Bulletin de l'Institut scientifique, Rabat, section Sciences de la Terre No. 23, 47-54.

[9] Sadki, D., Elmi, S. and Amhoud, H. (1999) Les formations jurassiques du Haut Atlas central marocain: Corrélation et évolution géodynamique. Le 1er Coll. Nat. Sur le Jur. Marocain, 122-123.

[10] Dominique, F.D., Pascale, L., Yves, M., Khomsi, S., Geoffrey, R., Saddiqi, O., et al. (2009) Mesozoic and Cenozoic Vertical Movements in the Atlas System (Algeria, Morocco, Tunisia). Tectonophysics, 475, 9-28.

[11] EL Kochri, A. (1996) Géométrie et mécanisme de déformation du Haut Atlas centro-oriental. Maroc. Thèse Doctorat d'Etat, Rabat, 200.

[12] Beuchamps, W., Barazani, M., Demnati, A. and Alji, M. (1996) Intracontinental Rifting and Inversion: Missour Basin Atlas Mountains, Morocco. AAPG Bulletin, 80, 1459-1482.

[13] ABHGZR (2009) Etude de synthèse hydrogéologique du Haut Atlas faisant partie des bassins du Guir, Rhéris et Ziz. $15-16$.

[14] LPEE (1993) Reconnaissance par prospection électriques Rich-Gourama. Administration de l'hydraulique direction de la recherche et planification de l'eau, Ministère des travaux publics.

[15] Ayarzaa, P., Alvarez-Lobatoa, F., Teixell, A., Arboleya, M., Teson, E., Julivertb, M., et al. (2005) Crustal Structure under the Central High Atlas Mountains (Morocco) from Geological and Gravity Data. Tectonophysics, 400, 67-84. http://dx.doi.org/10.1016/j.tecto.2005.02.009

[16] Ait Addi, A. (2002) Les série du Dogger du haut Atlas Marocaine (nord d'Errachidia/Boudnib): Lithostratigraphie, sedimentologie, stratigraphie séquentielle, cyclostratigraphie et évolution géodynamique. Thèse d’Etat, Université Ibno Tofaile faculté des sciences Kénitra, 54-63.

[17] Ait Addi, A. (2006) The Dogger Reef Horizons of the Moroccan Central High Atlas: New Data on Their Development. Journal of African Earth Sciences, 45, 162-172. http://dx.doi.org/10.1016/j.jafrearsci.2006.01.011

[18] Bouazza, M., Khattach, D., Houari, M. and Kaufmann, O. (2013) Apport du modèle géologique 3D à l'étude de la structure de l'aquifère profond d'Aïn Béni Mathar, Maroc Oriental. Bulletin de l'Institut Scientifique, Rabat, Section Sciences de la Terre, No. 35, 53-61. 